\title{
Navigating the Tensions: Women's Rights, Religion and Freedom of Religion or Belief
}

\author{
Nazila Ghanea | ORCID: 0000-0002-3086-5107 \\ Associate Professor in International Human Rights Law, \\ University of Oxford, United Kingdom \\ nazila.ghanea@law.ox.ac.uk
}

\begin{abstract}
Despite the normative integration between freedom of religion or belief (ғовв) and women's equality, these synergies are difficult to discern and there is a common misperception that women's rights to equality and FORB are clashing rights. This is compounded by the extensive religiously phrased reservations by states upon ratification of international treaties that amplify this misperception that FORB serves to restrict women's rights to equality. The advocacy groups supporting these rights, and also their normative sources in international human rights law instruments, are largely distinct. However, general non-discrimination provisions do address both, and General Comment no. 28 captures both rights holistically. The correctives to these misperceptions lie in reflecting upon the universality, indivisibility, interdependence, and interrelatedness of all human rights norms. They also lie in the realization that FORB is a right like any other. FOR B is neither a right of "religion" as such nor an instrument for support of religiously phrased reservations and limitations on women's rights to equality. This is particularly the case with harmful practices, as elaborated in the joint general recommendation/General Comment no. $3^{1}$ of the Committee on the Elimination of All Forms of Discrimination against Women and no. 18 of the Committee on the Rights of the Child however, the core principles also extend to other infringements of women's rights to equality. It is essential to (re)vitalize the synergies between FORB and women's equality in order to advance each of these rights, to be able to address overlapping rights concerns, and to adequately acknowledge intersectional claims. Furthermore, the relevant advocacy groups and human rights mechanisms need to give further attention to this as a priority matter.
\end{abstract}




\section{Keywords}

freedom of religion or belief - women's rights - equality - United Nations

\section{Introduction ${ }^{1}$}

Observing the synergies between freedom of religion or belief (FORB) and women's equality has not been made particularly straightforward by the architecture of international human rights law. The human rights sources that address FORB and women's rights to equality are distinct, and emerged from the lobbying of separate constituencies. ${ }^{2}$

This textually distinct basis is compounded by the thrust of the research and advocacy in women's rights, which strongly highlights that violations to women's rights are carried out in the name of religion, or at least that violations to women's rights are excused or postponed due to the intransigence of religious tradition and culture, whether perpetuated by state or non-state actors or a combination thereof. This serves to exacerbate the (mis)perception of a necessary and inevitable clash between women's rights to equality and FORB.

The juxtaposition of these two allegedly conflicting rights is conceptually untenable and counterproductive. It violates the universality of human rights in and of itself, since unless there is a holistic approach to human rights, its "indivisibility" and "interdependence" is denied. Furthermore, it fails to provide full redress to all, since it forces female claimants to "choose" to advance their right to either equality or FORB.

The purpose of this article is to seek to identify synergies as well as complexities between FORB and the right to women's equality through the analysis of various international human rights law documents impacting this topic.

1 This article was previously commissioned and published by the US Commission on International Religious Freedom entitled 'Women and Religious Freedom: Synergies and Opportunities' (July 2017).

2 See Brice Dickson, 'The United Nations and Freedom of Religion,' 44:2 International and Comparative Law Quarterly (1995); Arvonne S. Fraser, 'Becoming Human: The Origins and Development of Women's Human Rights,' 21 Human Rights Quarterly (1999). 


\section{International Human Rights Sources}

International human rights provisions in hard law upholding FORB do not specifically mention women's equality. Likewise, international human rights provisions in hard law protecting women's equality (e.g., CEDAW) make no mention of FORB or even of religion.

The general non-discrimination provisions of every key international human rights treaty, however, assert the need for non-discrimination whether on the basis of sex or religion. This is captured, inter alia, in Article 2.1 of the International Covenant on Civil and Political Rights (ICCPR $)^{3}$ and Article 2.2 of the International Covenant on Economic, Social and Cultural Rights (ICESCR). ${ }^{4}$ Non-discrimination both on grounds of sex and religion (or belief), ${ }^{5}$ therefore, necessarily reads into every human rights provision. Nevertheless, it remains the fact that the normative standards on FORB make no specific mention of women's equality, and the normative standards on women's rights make no specific mention of non-discrimination on the basis of religion or belief.

The normative standards upholding FORB are Article 18 of Universal Declaration of Human Rights (UDHR), Article 18 of the ICCPR, and the 1981 Declaration on the Elimination of All Forms of Intolerance and of Discrimination Based on Religion or Belief. ${ }^{6}$ These provisions make no mention of women's equality or even of non-discrimination on the basis of sex.

3 Article 2.1 of the ICCPR states, 'Each State Party to the present Covenant undertakes to respect and to ensure to all individuals within its territory and subject to its jurisdiction the rights recognized in the present Covenant, without distinction of any kind, such as race, colour, sex, language, religion, political or other opinion, national or social origin, property, birth or other status.'

4 Article 2.2 of the ICESCR states, 'The States Parties to the present Covenant undertake to guarantee that the rights enunciated in the present Covenant will be exercised without discrimination of any kind as to race, colour, sex, language, religion, political or other opinion, national or social origin, property, birth or other status.'

5 Note that the 1981 UN Declaration on the Elimination of All Forms of Intolerance and of Discrimination Based on Religion or Belief expands on the ICCPR and ICESCR language of "religion" to clarify that there should similarly be no discrimination on the basis of belief. (See its title, the language throughout the Declaration, and Article 2(2)).

6 Article 4 of the 1981 UN Declaration on the Elimination of All Forms of Intolerance and of Discrimination Based on Religion or Belief states: '1. All States shall take effective measures to prevent and eliminate discrimination on the grounds of religion or belief in the recognition, exercise and enjoyment of human rights and fundamental freedoms in all fields of civil, economic, political, social and cultural life. 2. All States shall make all efforts to enact or rescind legislation where necessary to prohibit any such discrimination, and to take all appropriate measures to combat intolerance on the grounds of religion or other beliefs in this matter.' 
It took a decade into the annual FORB resolutions-adopted by the United Nations (UN) Commission and UN Human Rights Council—for these resolutions to adopt explicit provisions since 1996. These resolutions have required the Special Rapporteur on FORB to adopt a gender perspective into his/her mandate only since $1996 .^{7}$

However, the language of FOR B provisions is that of 'everyone' and therefore irrespective of sex. On the one hand, the FORB sources we are raising here are very succinct. The first is an Article of a declaration, the second an Article of a convention, and the third a short (eight-Article) declaration. On the other hand, the main legal source dedicated to the advancement of women's equality is CEDAW - an extensive 3O-Article binding treaty. It makes no mention at all of FORB or indeed of religion. It does not even contain a standard nondiscrimination provision calling for no discrimination based on religion or other status. ${ }^{8}$ One author explains this in the following:

CEDAW rests on the idea that all women do share an interest in their gender's not being the basis of discrimination. Freedom from discrimination allows women to pursue all our other interests. CEDAW identifies all the ways in which women's identity can lead to discrimination and aims to guide countries in drafting and implementing policies to advance those interests. The issues outlined by CEDAW do not apply merely to a particular subset of women but, rather, to all women, regardless of any other cross-cutting identity. ${ }^{9}$

These omissions are in some ways compensated by the UN Human Rights Committee, which is the treaty monitoring body with oversight over the realisation of the ICCPR. Since the ICCPR has provisions relating to nondiscrimination on a number of status grounds (Articles 2 and 26), to the

7 See Michael Wiener, 'Freedom of Religion or Belief and Sexuality—Tracing the Evolution of the Special Rapporteur's Mandate Practice over zo Years,' Oxford Journal of Law and Religion (2017).

8 Article 1 of CEDAW only defines discrimination against women and makes no mention of other grounds of discrimination. It states, 'For the purposes of the present Convention, the term "discrimination against women" shall mean any distinction, exclusion or restriction made on the basis of sex which has the effect or purpose of impairing or nullifying the recognition, enjoyment or exercise by women, irrespective of their marital status, on a basis of equality of men and women, of human rights and fundamental freedoms in the political, economic, social, cultural, civil or any other field.'

9 Liza Baldez, 'The UN Convention to Eliminate All Forms of Discrimination Against Women (CEDAW): A New Way to Measure Women's Interests', 7:3 Politics \& Gender (2011), p. 422. 
equal enjoyment of rights by men and women (Article 3), and also on FORB (Article 18), it is not surprising then that the UN Human Rights Committee is able to address FORB and women's equality with perception and experience in its General Comment $28 .{ }^{10}$

General Comment 28 elaborates on its standalone non-discrimination on the basis of sex provision in Article 3 'to ensure the equal right of men and women to the enjoyment of all civil and political rights.'11 This is distinct from the ICCPR's general non-discrimination provision in Articles 2(1) and $26 .{ }^{12}$ General Comment 28 emphasises that 'all human beings should enjoy the rights provided for in the Covenant, on an equal basis and in their totality ... States should ensure to men and women equally the enjoyment of all rights provided for in the Covenant. ${ }^{\prime 13}$ The UN Human Rights Committee requires that state parties take 'all necessary steps' to enable the equal enjoyment of everyone to ICCPR rights, whether in the public or private sectors, ${ }^{14}$ or during states of emergency ${ }^{15}$ or conflict. ${ }^{16}$ The committee recognizes that this will require positive measures as well as measures of protection, including public education as to the role of women, the empowerment of women, changes to domestic legislation and tracking their effectiveness, and human rights training for officials. ${ }^{17}$

$10 \quad$ Human Rights Committee, General Comment 28: Equality of Rights between Men and Women, CCPR/C/21/Rev.1/Add.10 (2000).

11 ICCPR, Article 3.

12 ICCPR, Article 2(1) states: 'Each State Party to the present Covenant undertakes to respect and to ensure to all individuals within its territory and subject to its jurisdiction the rights recognized in the present Covenant, without distinction of any kind, such as race, colour, sex, language, religion, political or other opinion, national or social origin, property, birth or other status.' ICCPR, Article 26 states: 'All persons are equal before the law and are entitled without any discrimination to the equal protection of the law. In this respect, the law shall prohibit any discrimination and guarantee to all persons equal and effective protection against discrimination on any ground such as race, colour, sex, language, religion, political or other opinion, national or social origin, property, birth or other status.'

13 General Comment 28, para. 2.

14 General Comment 28, para. 4 and para. 31.

15 General Comment 28, para. 7 .

16 General Comment 28, para. 8.

17 General Comment 28, para. 3 . 
In summarizing the above, we note that textually both sex and religion are prohibited among the grounds of discrimination in general provisions of the International Bill of Rights (UDHR, ICCPR, ICESCR); however, both sets of human rights provisions (FORB and women's equality) take insufficient account of the other. The international human rights instrument that most effectively addresses related concerns, as discussed, is General Comment 28, as the UN Human Rights Committee is the only treaty body with provisions to be able to most readily address both FORB and women's equality.

There are a number of reasons why there is such persistence in the presumption that FORB and the advancement of women's rights to equality necessarily and inevitably clash. A dominant reason for this is the fact that numerous reservations to human rights concerning women and girls are asserted in the name of religion (usually a 'state religion') and religious laws. As one author coins it, there is a 'frequent invocation' of religious norms as 'defense in order to oppose gender equality claims. ${ }^{18}$ Another reason is the gravity of the violations of the human rights of women and girls carried out in the name of (religious) tradition. Often the state then endorses violations, or neglects to act effectively on them.

In general, reservations to human rights treaties are distinctive to reservations to other treaties. This is because many such reservations take the form of rejection of a human rights norm, as opposed to an interpretation of its scope, [and] they are more likely to be found incompatible with the objects and purposes $^{\prime 19}$ of the treaty. Furthermore, the 'deterrent effect of reciprocity does not apply to human rights treaties ... because it regulates domestic behavior rather than relations among contracting parties. ${ }^{20}$

Many of these reservations and declarations to human rights provisions concerning women's rights are based on "religious" justifications, and particularly to Articles 2, 5(a), and 16 of CEDAW. ${ }^{21}$ Article 2 of CEDAW outlines the

18 Frances Raday, 'Culture, Religion, and Gender,' 1:4 International Journal of Constitutional Law (2003), p. 665.

19 E/CN.4/Sub.2/1999/28, 28 June 1999, Working paper submitted by Ms Françoise Hampson: 'Reservations to Human Rights Treaties,' para. 14.

20 Eric Neumayer, 'Qualified Ratification: Explaining Reservations to International Human Rights Treaties,' 36:2 Journal of Legal Studies (2007), p. 399.

21 Article 2 of CEDAW states: 'States Parties condemn discrimination against women in all its forms, agree to pursue by all appropriate means and without delay a policy of eliminating discrimination against women and, to this end, undertake: (a) To embody the principle of 
range of measures that state parties will take 'through all appropriate means and without delay' to eliminate discrimination against women. Article 5(a) also determines that state parties will take 'all appropriate measures' in order to 'modify the social and cultural patterns of conduct of men and women' in order to eliminate prejudices and 'customary and other practices' based on 'the idea of the inferiority or the superiority of either of the sexes or on stereotyped roles for men and women.' Article 16 of CEDAW addresses marriage and family life and the need to tackle discrimination and inequality in all aspects of marriage and family life. These reservations and declarations come in a variety of forms, and a selection is listed in table 1 below.

the equality of men and women in their national constitutions or other appropriate legislation if not yet incorporated therein and to ensure, through law and other appropriate means, the practical realization of this principle; (b) To adopt appropriate legislative and other measures, including sanctions where appropriate, prohibiting all discrimination against women; (c) To establish legal protection of the rights of women on an equal basis with men and to ensure through competent national tribunals and other public institutions the effective protection of women against any act of discrimination; (d) To refrain from engaging in any act or practice of discrimination against women and to ensure that public authorities and institutions shall act in conformity with this obligation; (e) To take all appropriate measures to eliminate discrimination against women by any person, organization or enterprise; (f) To take all appropriate measures, including legislation, to modify or abolish existing laws, regulations, customs and practices which constitute discrimination against women; (g) To repeal all national penal provisions which constitute discrimination against women.' Article 16 of CEDAW states: '1. States Parties shall take all appropriate measures to eliminate discrimination against women in all matters relating to marriage and family relations and in particular shall ensure, on a basis of equality of men and women:

(a) The same right to enter into marriage; (b) The same right freely to choose a spouse and to enter into marriage only with their free and full consent; (c) The same rights and responsibilities during marriage and at its dissolution; (d) The same rights and responsibilities as parents, irrespective of their marital status, in matters relating to their children; in all cases the interests of the children shall be paramount; (e) The same rights to decide freely and responsibly on the number and spacing of their children and to have access to the information, education and means to enable them to exercise these rights; (f) The same rights and responsibilities with regard to guardianship, wardship, trusteeship and adoption of children, or similar institutions where these concepts exist in national legislation; in all cases the interests of the children shall be paramount; (g) The same personal rights as husband and wife, including the right to choose a family name, a profession and an occupation; (h) The same rights for both spouses in respect of the ownership, acquisition, management, administration, enjoyment and disposition of property, whether free of charge or for a valuable consideration. 2. The betrothal and the marriage of a child shall have no legal effect, and all necessary action, including legislation, shall be taken to specify a minimum age for marriage and to make the registration of marriages in an official registry compulsory.' 


\begin{abstract}
Algeria
Article 2:

The Government of the People's Democratic Republic of Algeria declares that it is prepared to apply the provisions of this Article on condition that they do not conflict with the provisions of the Algerian Family Code.
\end{abstract}

\title{
Article 16 :
}

The Government of the People's Democratic Republic of Algeria declares that the provisions of Article 16 concerning equal rights for men and women in all matters relating to marriage, both during marriage and at its dissolution, should not contradict the provisions of the Algerian Family Code.

\section{Egypt}

In respect of Article 16 :

Reservation to the text of Article 16 concerning the equality of men and women in all matters relating to marriage and family relations during the marriage and upon its dissolution, without prejudice to the Islamic Sharia's provisions whereby women are accorded rights equivalent to those of their spouses so as to ensure a just balance between them. This is out of respect for the sacrosanct nature of the firm religious beliefs which govern marital relations in Egypt and which may not be called in question and in view of the fact that one of the most important bases of these relations is an equivalency of rights and duties so as to ensure complementary which guarantees true equality between the spouses. The provisions of the Sharia lay down that the husband shall pay bridal money to the wife and maintain her fully and shall also make a payment to her upon divorce, whereas the wife retains full rights over her property and is not obliged to spend anything on her keep. The Sharia therefore restricts the wife's rights to divorce by making it contingent on a judge's ruling, whereas no such restriction is laid down in the case of the husband.

\section{General reservation on Article 2:}

The Arab Republic of Egypt is willing to comply with the content of this Article, provided that such compliance does not run counter to the Islamic Sharia. 


\section{India}

Declarations:

i) With regard to Articles 5 (a) and 16 (1) of the Convention on the Elimination of All Forms of Discrimination Against Women, the Government of the Republic of India declares that it shall abide by and ensure these provisions in conformity with its policy of non-interference in the personal affairs of any Community without its initiative and consent.

ii) With regard to Article 16 (2) of the Convention on the Elimination of All Forms of Discrimination Against Women, the Government of the Republic of India declares that though in principle it fully supports the principle of compulsory registration of marriages, it is not practical in a vast country like India with its variety of customs, religions and level of literacy.

\section{Ireland}

Articles 16, $1(d)$ and $(f)$ :

Ireland is of the view that the attainment in Ireland of the objectives of the Convention does not necessitate the extension to men of rights identical to those accorded by law to women in respect of the guardianship, adoption and custody of children born out of wedlock and reserves the right to implement the Convention subject to that understanding.

\section{Israel}

The State of Israel hereby expresses its reservation with regard to Article 16 of the Convention, to the extent that the laws on personal status which are binding on the various religious communities in Israel do not conform with the provisions of that Article.

\section{Maldives}

The Government of the Republic of Maldives reserves its right to apply Article 16 of the Convention concerning the equality of men and women in all matters relating to marriage and family relations without prejudice to the provisions of the Islamic Sharia, which govern all marital and family relations of the 100 percent Muslim population of the Maldives. 


\section{Saudi Arabia}

In case of contradiction between any term of the Convention and the norms of Islamic law, the Kingdom is not under obligation to observe the contradictory terms of the Convention. ${ }^{\mathrm{a}}$

a United Nations Treaty Collection, ratifications, declarations, and reservations to the Convention on the Elimination of All Forms of Discrimination against Women, available at https://treaties.un.org.

The religiously phrased ${ }^{22}$ reservations $^{23}$ listed above are indicative of the reasons why perceptions of religion (and FORB) necessarily being anti-women are so persuasive. These reservations have extensive implications and serve to seriously restrict women's rights. ${ }^{24}$

The reservation from Algeria regarding Article 2, for example, states that the elimination of discrimination against women is subject to the condition that they do not conflict with provisions of the Family Code. It does not, however, specify exactly what this implies for the rights upheld in CEDAW. Egypt's reservation similarly restricts without specificity but subject to the Islamic Sharia. India's declaration regarding Articles 5(a) and 16(1) means the state's

22 The term 'religiously phrased reservations' is used in order to indicate that this paper will not be carrying out a theological assessment as to the religious legitimacy or necessity of such reservations by state parties to CEDAW.

23 CEDAW General Recommendations No. 4 and No. 20. Article 28 of CEDAW deals with the reservations entered into by the state parties and declares any reservation incompatible with the object and purpose of the convention to be impermissible. 'Reservation' is defined under Article 2 of Vienna Convention on the Law of Treaties. See http://www.uni cef.org/french/crc/files/Definitions.pdf. See also: http://www.un.org/womenwatch/daw/ cedaw/res ervations.htm and http://www.un.org/womenwatch/daw/cedaw/reservations -country.htm.

24 Examples of religiously phrased reservations to CEDAW include: Bahrain: 'The Kingdom of Bahrain makes reservations with respect to the following provisions of the Convention: ... - Article 16, in so far as it is incompatible with the provisions of the Islamic Shariah'; and Mauritania: 'Having seen and examined the United Nations Convention on the Elimination of All Forms of Discrimination against Women, adopted by the United Nations General Assembly on 18 December 1979, have approved and do approve it in each and every one of its parts which are not contrary to Islamic Sharia and are in accordance with our Constitution.' Taken from: http://www.un.org/womenwatch/ daw/cedaw/reservations-country.htm. 
obligation to address prejudices on the inferiority of women and stereotyped roles for them and discrimination and inequality against them in marriage and family life will only be addressed with the 'initiative and consent' of each community, since personal status laws are the prerogative of specific communities. It suggests the government is not even prepared to initiate discussion of this topic with the communities. This raises a complicating factor of the various entanglements of states with religion, religious authorities, and communities. These entanglements deeply implicate questions around religion and limitations on women's rights. These state-religion(s) entanglements impact 'laws, regulations or policies' 25 on many levels, each of which may have political vested interests and patrimonial linkages with state authorities. In this context, the need to encourage states 'to refrain from misusing the argument of cultural or religious relativism to evade their responsibilities' ${ }^{26}$ with regard to women's rights cannot be overstated.

The implication of these reservations for women's rights is given much attention by human rights bodies and in the academic literature. What is often forgotten in assessing these religiously phrased reservations and declarations restricting women's rights, however, is that they also restrict a human rights understanding of FORB itself. ${ }^{27}$ After all, FORB, as a human right, 'does not protect religions per se (e.g., traditions, values, identities, and truth claims) but aims at the empowerment of human beings, as individuals and in community with others. This empowerment component is something that freedom of religion or belief has in common with all other human rights.'28

The above reservations effectively impose a restriction on 'everyone' from coming to an understanding of their own religion, and in manifesting their religion or belief in accordance with that understanding. For example, a Catholic woman, a Muslim couple, a Jewish divorcee, or a Christian child will have many aspects of their personal status determined in singular ways

25 Report of the Special Rapporteur Abdelfattah Amor, Study on Freedom of Religion or Belief and the Status of Women in the Light of Religion and Traditions, E/CN.4/2002/73/Add.2 (2009), para. 237.

26 Ibid., para. 221.

27 For detailed discussion, see Heiner Bielefeldt, Nazila Ghanea, and Michael Wiener, Freedom of Religion or Belief, An International Law Commentary (Oxford: Oxford University Press, 2016).

28 Report of the Special Rapporteur Heiner Bielefeldt on freedom of religion or belief, Addressing the Interplay of Freedom of Religion or Belief and Equality between Men and Women, A/68/29o (2013), para. 70. 
regardless of whether they have adopted or changed the religion or belief of their birth/designation, whether they understand their religious laws in that way, and whether they wish to manifest in the manner that was captured by a particular religious understanding and denomination at the time when that particular personal status law enshrined it in law in that country. These restrictions therefore limit not only women's rights, but also FORB, and particularly women's rights to FORB.

To better understand the impact of religiously phrased reservations and declarations on FORB itself, the distinction between FORB and "religion" as such has to be better recognised. A sharper distinction has to be drawn between mere claims of FORB and those assertions that have been carefully assessed by independent legal authorities to be in line with international human rights standards. Regretfully, this point is often lost. Indeed, 'the cultural defense or claims of religious freedom are used to oppose women's demands for gender equality'; ${ }^{29}$ but 'used' is not at all the same as saying it is legitimately so in human rights terms. Some conflate or confuse this. It is this confusion that leads some to rank the human right to FORB as problematic in and of itself, and an obstacle to the achievement of other human rights. The assertion that 'where there is a clash between cultural practices or religious norms and the right to gender equality, it is the right to gender equality that must have normative hegemony'30 is correct in human rights terms. This is because the very rationale of human rights is that rights cannot be extinguished or vitiated for the sake of particular patterns of conduct. However, such clashes between gender equality and 'religious norms' are not clashes with FORB. In fact the Special Rapporteur on FORB has categorically reminded us that we should not set up 'the idea that freedom of religion or belief and equality between men and women are norms standing in opposition to each other ... one should not turn concrete conflicts between (seemingly or factually) competing human rights issues into abstract antagonisms on the normative level itself.' 31

There are numerous tools for responding to these challenges. The first and most straightforward response is that all rights have been recognized to be 'universal, indivisible and interdependent and interrelated.'32 It follows from

29 Frances Raday, 'Culture, Religion, and Gender,' 1:4 International Journal of Constitutional Law (2003), p. 710.

$30 \quad$ Ibid.

31 Addressing the Interplay of Freedom of Religion or Belief and Equality between Men and Women, para. 21.

32 Article 1(5) of the Vienna Declaration and Programme of Action states, 'All human rights are universal, indivisible and interdependent and interrelated. The international 
this that FORB and women's rights necessarily need to be read together-in a 'holistic understanding of human rights' ${ }^{3}$ - and serve to facilitate and be enjoyed alongside one another. Second, it is clear that no right can be used as the basis for extinguishing other rights, nor to denying rights and freedoms to others. This is reflected not only in the limitation grounds of the 'rights and freedoms of others, ${ }^{34}$ but also in the provision in human rights instruments referred to as the 'prohibition of abuse of rights. ${ }^{35}$ And, third, the underlying thrust of non-discrimination throughout human rights instruments underscores that FORB needs to be cognizant of non-discrimination on the basis of sex, and women's rights need to be vigilant of non-discrimination on the basis of religion (or belief). ${ }^{36}$

Despite the above, synergies between women's rights and FORB face a number of serious challenges. Numerous violations of the rights of girls and women continue in the name of religion, or are restricted on the basis of religion, whether by state or non-state actors. However, we should not confuse violations and restrictions in the name of religion-particularly by state actorsand FORB; the two need clear disentanglement and this will be addressed in section vi below.

community must treat human rights globally in a fair and equal manner, on the same footing, and with the same emphasis. While the significance of national and regional particularities and various historical, cultural and religious backgrounds must be borne in mind, it is the duty of States, regardless of their political, economic and cultural systems, to promote and protect all human rights and fundamental freedoms.'

33 Addressing the Interplay of Freedom of Religion or Belief and Equality between Men and Women, para. 19 .

34 Article 5(1) of the ICCPR states, 'Nothing in the present Covenant may be interpreted as implying for any State, group or person any right to engage in any activity or perform any act aimed at the destruction of any of the rights and freedoms recognized herein or at their limitation to a greater extent than is provided for in the present Covenant.'

35 See also Article 17 of the ECHR, which states, 'Nothing in this Convention may be interpreted as implying for any State, group or person any right to engage in any activity or perform any act aimed at the destruction of any of the rights and freedoms set forth herein or at their limitation to a greater extent than is provided for in the Convention.'

36 'Or belief' is put in brackets as a number of international human rights instruments only mention 'religion' and not 'religion or belief' (e.g., Article 2.1 of the ICCPR and Article 2.2 of the ICESCR). However, FORB instruments would suggest 'religion' should be read as 'religion or belief' due to language of Article 18 of the ICCPR and expanded in General Comment 22 of the UN Human Rights Committee. 
The question of how effective the UN international standards and tools have been in addressing the synergies between FORB and the rights of women and girls leads us to a variegated response.

It is clear that the international human rights law's suspicion, sometimes even the hostility of human rights advocates, lies primarily in one direction: that is, of advocates of women's rights against FORB. Though FORB standards have not made specific mention of women's equality, the main reason for this is that there is no convention and therefore no corresponding treaty body overseeing and developing the FORB standards. If there had been a standalone human rights convention on FORB and a supervising treaty body-as in the case of women's rights and CEDAW - there is no doubt it would have issued a General Comment on women's rights, likely in the late 199os or early 20oos, just as many other treaty bodies did. ${ }^{37}$ CEDAw, however, has had the opportunity to comment on FORB, but has not chosen to do so in its 34 general recommendations to date. Sally Engle Merry contends that 'CEDAW, like the rest of the human rights regime, assumes that culture, custom, or religion should not condone violations of human rights. ${ }^{38}$ Taking the "universalizing approach" that is structured in the convention itself, Merry speaks of the CEDAW committee members presenting 'a united front against recalcitrant or evasive government representatives' and 'uniformly' condemning 'injurious cultural practices'39 and, by extension, also religion. This, in fact, can be traced to CEDAW's regular conflation of (injurious) culture, tradition, and religion as well as its very concept of culture. As Merry explains,

There is an old vision of culture as fixed, static, bounded, and adhered to by rote juxtaposed to a more modern understanding of culture as a process of continually creating new meanings and practices that are products of power relationships and open to contestation among members of

37 See, for example, the General Recommendation of the Committee on the Elimination of Racial Discrimination, esp. General Recommendation No. 25, Gender Related dimensions of Racial discrimination (2000).

38 Sally Engle Merry, 'Gender Justice and CEDAW: The Convention on the Elimination of All Forms of Discrimination against Women,' 9:1-2 Journal of Women of the Middle East and the Islamic World (2011), p. 54.

Ibid., p. 54 . 
the group and by outsiders. In CEDAW discussions, when culture is raised as a problem, its old meaning is invoked. ${ }^{40}$

Frances Raday goes so far as to state that 'the clash between culture or religion and gender equality rights has become a major issue in the global arena. It is probably the most intractable aspect of the confrontation between cultural and religious claims and human rights doctrine. ${ }^{41}$

The strongest mechanism that FORB has to generate new synergies is the mandate of the Special Rapporteur on FORB, which came into being in 1986. The mandate has raised the question of FORB and women's equality with regularity in reports and communications regarding specific cases. The mandate also has dedicated two reports exclusively to FORB and gender. ${ }^{42}$ These have served to champion the importance of women's equality and ensuring that "religion" or FORB are not claimed as bases for the violation of women's rights.

There has not been a reciprocal interest from CEDAW or the UN Working Group on the issue of discrimination against women in law and practice. In fact, any mentions have only highlighted "religion" (not specifically FORB) as the basis for the abuse of women's rights. Neither the synergies between women's rights to equality and FORB, nor the intersection of women's claims to FORB, are addressed. In fact, this is part and parcel of a broader critique of CEDAW: that the committee needs 'a critical methodological countercheck to ensure that any gender analysis of individual communications is based on a holistic understanding of alleged victims' multiple identities, rather than essentialist understandings of sex/gender. ${ }^{\prime 3}$

The impact this has had in practical terms is that there is a dearth of standards, sources, and jurisprudence addressing intersections and synergies between women's rights to equality and FORB. This runs the risk of both inadequate protections and continued tension and polarization around this cluster of human rights concerns. Considering the range of challenges that arise in

$40 \quad$ Ibid., p. 56.

41 Frances Raday, 'Culture, Religion, and Gender,' 1:4 International Journal of Constitutional Law (2003), p. 665.

42 Report of the Special Rapporteur Heiner Bielefeldt on freedom of religion or belief, 2013, Addressing the Interplay of Freedom of Religion or Belief and Equality between Men and Women, A/68/29o; Report of the Special Rapporteur Abdelfattah Amor, 20o9, Study on Freedom of Religion or Belief and the Status of Women in the Light of Religion and Traditions, E/CN.4/2002/73/Add.2.

43 Simone Cusack and Lisa Pusey, 'CEDAW and the Rights to Non-Discrimination and Equality,' 14:1 Melbourne Journal of International Law (June 2013), p. $3^{8 .}$ 
this sphere, as outlined below, the perpetuation of such polarization is increasingly concerning.

\section{5 Violations That Arise: Women's Rights/Religion “Clashes"?}

In light of the challenges in examining correlations between women's rights to equality and FORB, it is important to highlight the main human rights violations that lead to the overall misperception of a necessary clash between these rights. The object of this article is certainly not to gloss over these serious human rights violations or deflect attention from them.

Such violations are covered in some detail in General Comment No. $28^{44}$ of the UN Human Rights Committee, as well as in joint General Recommendation No. 31 of CEDAW/General Comment No. 18 of the CRC. General Comment 28 asserts that inequality in the enjoyment of rights by women throughout the world is deeply embedded in tradition, history and culture, including religious attitudes. ${ }^{\prime 5}$ It calls on state parties to ensure that 'traditional, historical, religious or cultural attitudes'46 do not serve as the basis of justifying 'violations of women's right to equality before the law and to equal enjoyment of all Covenant rights. ${ }^{47}$ In fact, it calls on state parties to raise such 'traditional, historical, religious or cultural attitudes' with the UN Human Rights Committee and share with it the measures taken to 'overcome' them. ${ }^{48}$

The joint general recommendation/comment addresses 'harmful practices,' listed below in table 2, which are defined as practices 'grounded in discrimination based on sex, gender and age, among other things,' often associated with 'serious forms of violence' or constituting violence themselves and - critically for our topic - they have 'often been justified by invoking sociocultural and religious customs and values. ${ }^{49}$

It is clear from the above that detailed attention to the violations against the equality and human rights of women is rightly being given. The gravity of these violations remains unchanged whether they are carried out in the name of religion, tradition, or custom, or an amalgam of these. However, religion is

\footnotetext{
44 General Comment 28, para. 4 and para. 31.

45 General Comment 28, para. 5 .

46 General Comment 28, para. 5 .

47 General Comment 28, para. 5 .

48 General Comment 28, para. 5 .

$49 \mathrm{CEDAW} / \mathrm{C} / \mathrm{GC} / 31 / \mathrm{CRC} / \mathrm{C} / \mathrm{GC} / 18$, CEDAW and CRC, 2014, Joint General Recommendation No. $3^{1}$ of the Committee on the Elimination of Discrimination against Women/General Comment No. 18 of the UN Committee on the Rights of the Child on harmful practices, para. 7 .
} 
The most prevalent and well-documented of the harmful practices according to CEDAW and the CRC are: ${ }^{\mathrm{a}}$

- Female genital mutilation ${ }^{\text {b }}$

- Child and/or forced marriage: To this the UN Human Rights Committee adds equality in marriage and the possibility to 'marry freely.' It goes on, 'Men and women have the right to enter into marriage only with their free and full consent, and States have an obligation to protect the enjoyment of this right on an equal basis.'c It also calls for the setting of the minimum age for marriage to be done 'on the basis of equal criteria for men and women. These criteria should ensure women's capacity to make an informed and uncoerced decision.' ${ }^{\text {d }}$

- Polygamy: The UN Human Rights Committee goes so far as to refer to polygamy as 'an inadmissible discrimination against women' that should be 'definitely abolished wherever it continues to exist.'e

- Crimes committed in the name of so-called honor: The UN Human Rights Committee calls on states to ensure punishments for such crimes.

- Dowry-related violence ${ }^{\mathrm{f}}$

Other violations impacting the girl child include:

- 'Pre-natal sex selection and abortion of female fetuses'g

- Female infanticide ${ }^{\mathrm{h}}$

- 'Neglect of girls (linked to the preferential care and treatment of boys)'i

- Trafficking of children ${ }^{\mathrm{j}}$

a Joint General Recommendation/comment on harmful practices, para. 7 .

b CCPR/C/21/Rev.1/Add.10, General Comment No. 28, para. 11. Furthermore see: CEDAW/C/ GC/14, CEDAW, General Recommendation No. 14, Female Circumcision (1990).

c CCPR/C/21/Rev.1/Add.10, General Comment 28, para. 23. See also CEDAW, General Recommendation No. 21, Equality in marriage and family relations, CEDAW/C/GC/21 (1994); and CEDAW, General Recommendation No. 29. Economic consequences of marriage, family relations and their dissolution, CEDAW/C/GC/29 (2013).

d General Comment No. 28, para. 23.

e General Comment No. 28, para. 23 .

f General Comment No. 28, para. 10.

g General Comment No. 28, para. 5 .

h General Comment No. 28, para. 10.

i Joint General Recommendation/comment on harmful practices, para. 9 .

j General Comment No. 28, para. 12. 
Other violations concerning women and marriage include:

- Equal rights for women in the custody and care of children, the religious and moral education of children, passing on nationality to children and the ownership and administration of property, retaining one's original family name or choosing a new one, and equality during marriage as participating 'equally in responsibility and authority within the family.'k

Violations concerning women and divorce or remarriage include:

- Equal grounds in 'divorce and annulment ... property distribution, alimony and the custody of children' and equal inheritance rights ${ }^{\mathrm{l}}$

- Ensuring the following is addressed by abolishing the relevant laws and eradicating the relevant practices: 'States impose restrictions on remarriage by women as compared to men. Also the right to choose one's spouse may be restricted by laws or practices that prevent the marriage of a woman of a particular religion with a man who professes no religion or a different religion.' $m$

\section{Otherviolations:}

- Ensuring laws do not impose more severe penalties on women for offenses than on men. ${ }^{\mathrm{n}}$

- 'Regulation of clothing to be worn by women in public'o

- 'Practices which may deprive women of their liberty on an arbitrary or unequal basis, such as by confinement within the house'p

- 'Any legal provision or any practice which restricts women's right to freedom of movement ... legal or de facto requirements which prevent women from travelling'q

- 'Access to justice and the right to a fair trial ... [and ensuring] women equal access to legal aid, in particular in family matters'r

- Recognition 'everywhere as a person before the law's

k General Comment No. 28, para. 25 .

1 General Comment No. 28, para. 26.

m General Comment No. 28, para. 24 .

n General Comment No. 28, para. 31.

o General Comment No. 28, para. 13 .

p General Comment No. 28, para. 14.

q General Comment No. 28, para. 16.

r General Comment No. 28, para. 18.

s General Comment No. 28, para. 19. 
- Impact of 'poverty and deprivation' on women ${ }^{\mathrm{t}}$

- 'Domestic and other types of violence against women, including rape'u

- 'Trafficking of women ... forced prostitution ... slavery'v

- The burning of widowsw

- Stoning ${ }^{\mathbf{x}}$

t General Comment No. 28, para. 10.

u General Comment No. 28, para. 11. See also CEDAw, General Recommendation No. 19, Accelerating elimination of gender-based violence against women, CEDAW/C/GC/19 (1992). This defines gender-based violence as 'a form of discrimination that seriously inhibits women's ability to enjoy rights and freedoms on a basis of equality with men' (para. 1).

v General Comment No. 28, para. 12.

w General Comment No. 28, para. 10.

$\mathrm{x}$ Joint General Recommendation/comment on harmful practices, para. 9.

among the asserted grounds for women's rights violations, though this invocation of religion may well be covering a range of socioeconomic, traditional, political, and other objectives for states and have a tenuous relationship with "religion" as such.

To begin with, harmful practices by definition constitute a denial of dignity and integrity, amount to discrimination, and are imposed on women and children 'regardless of whether the victim provides, or is able to provide, full, free and informed consent. ${ }^{50}$ As such, even if they were to be accepted as manifestations of FORB under Article 18 of the ICCPR, these practices would be subject to limitations on such manifestation.

Additionally, not all assertions of FORB can be accepted as manifestations of religion or belief. It has to be established that the religion or belief itself is of a certain 'cogency, seriousness, cohesion and importance. ${ }^{51}$ The relationship and nexus between religion or belief and manifestation also needs clarifying. Having done so, it should also be noted that manifestations of religion or belief

\footnotetext{
$5^{\circ}$ Joint General Recommendation/comment on harmful practices, para. 16.

51 Campbell and Cosans v. UK, European Court of Human Rights, Application No. 7511/76, Judgment of 25 February 1982.
} 
ICCPR rights that may be violated by harmful practices:

non-discrimination (Article 2)

equal rights of men and women (Article 3)

right to life (Article 6)

the prohibition of torture (Article 7)

the prohibition of slavery (Article 8)

liberty and security of person (Article 9)

respect for dignity (Article 10)

liberty of movement (Article 12)

due process (Article 14)

equality before the law (Article 16)

privacy, honor, and reputation (Article 17)

equality to marriage, during marriage, and at its dissolution (Article 23)

the rights of children (Article 24)

equality before the law and equal protection of the law (Article 26)

may be subject to 'such limitations as are prescribed by law and are necessary to protect public safety, order, health, or morals or the fundamental rights and freedoms of others. ${ }^{52}$ The definition of harmful practices, as defined in the joint general recommendation/comment, would strongly suggest that since such manifestations lead to the denial of dignity and integrity and amount to discrimination, ${ }^{53}$ they should indeed be subject to limitation.

Furthermore, the ICCPR also insists that 'nothing' in the covenant 'may be interpreted as implying for any State, group or person any right to engage in any activity or perform any act aimed at the destruction of any of the rights and freedoms recognized herein or at their limitation to a greater extent than is provided for in the present Covenant. 54 Since harmful practices can violate numerous ICCPR rights (see table 3 above) the extensive application of Article 5 is very salient.

The above establishes that actions that result in harmful practices cannot be seen-in human rights terms - as legitimate manifestations of FORB. Indeed, the assertion of any human rights claim cannot be utilized to extinguish other rights. Nor can the assertion of one person or group of an individual's claims be a legitimate basis for the elimination of the rights of others. This has succinctly

\footnotetext{
52 ICCPR, Article 18(3).

53 Joint General Recommendation/comment on harmful practices, para. 16.

54 ICCPR, Article 5(1).
} 
been captured in the often-recalled reference in the Vienna Declaration and Programme of Action that 'all human rights are universal, indivisible and interdependent and interrelated. 55

If FORB cannot serve as one of the justifications for harmful practices, then what role can it play in responding to harmful practices against women and girls? The joint general recommendation/comment recognizes the need for integrated vertical and horizontal efforts at the national level to 'prevent and address all forms of harmful practices. ${ }^{56}$ Horizontal coordination is that across sections: 'including education, health, justice, social welfare, law enforcement, immigration and asylum and communications and media'; vertical coordination is that 'between actors at the local, regional and national levels and with traditional and religious authorities. ${ }^{57}$ The role of religious authorities, leaders, nongovernmental organizations, and communities in preventing and addressing harmful practices is well taken. FORB would expand this to those who mobilize on grounds of belief to prevent and address such practices. FORB would also support the individual to understand, interpret, ${ }^{58}$ and manifest their religion in harmony with respecting the dignity, integrity, ${ }^{59}$ and free volition of others. FORB would further encourage everyone to consider whether their religious laws should be forcibly imposed on others, especially others who are unable 'to provide, full, free and informed consent. ${ }^{60}$

The joint general recommendation/comment points precisely to this dilemma in state parties with plural legal systems, even where there are laws in existence that prohibit harmful practices, because such prohibitions 'may not be enforced effectively because the existence of customary, traditional or religious laws may actually support those practices, ${ }^{\prime 61}$ and due to 'prejudices and weak capacity ... among judges in customary and religious courts or traditional adjudication'62 without sufficient review and scrutiny by the state. It therefore calls on state parties to repeal all legislation that condones, allows, or leads to harmful practices, including traditional, customary, or religious laws, and any legislation that accepts the defense of honor as a defense or mitigating factor in the commission of crimes in the name of so-called honor; ${ }^{63}$ take legislative

55 Vienna Declaration and Programme of Action, 1993, Article 1(5).

56 Joint General Recommendation/comment on harmful practices, para. 34.

57 Joint General Recommendation/comment on harmful practices, para. 34.

$5^{8}$ There is a vibrant literature here, by way of example, around Muslim reformist thinking and Jewish family law. Publications in this area, for example, include the works of Abdullahi Ahmed An-Na'im, Mashood Baderin, and Ayelet Shachar.

59 Joint General Recommendation/comment on harmful practices, para. 16.

6o Joint General Recommendation/comment on harmful practices, para. 16.

61 Joint General Recommendation/comment on harmful practices, para. 43.

62 Joint General Recommendation/comment on harmful practices, para. 44.

63 Joint General Recommendation/comment on harmful practices, para. 55(c). 
and other appropriate measures to eradicate 'all cultural or religious practices which jeopardize the freedom and well-being of female children'; ${ }^{64}$ adopt and amend legislation in line with international provisions; and ensure that such legislation 'takes precedence over customary, traditional or religious laws that allow, condone or prescribe any harmful practice, especially in countries with plural legal systems.' 65

To this understanding of harmful practices against women and girls we need to add another set of serious violations of a different scale and gravity: mass violations such as systematic mass rape against women and girls, women and girls forced into slavery, forcible conversion, forced marriage, abductions and other sexual violence, enforced dress codes and restrictions on free movement, health care, and educational access. These are most readily in the news in recent years in light of the violations committed by the Islamic State of Iraq and Syria (ISIS), but are not unique to them. These violations are carried out by these extremist groups in the name of religion but by non-state actors. Although horizontal and vertical actions recommended tackling harmful practices at the national level ${ }^{66}$ will not operate in the same way against these violations in territories where IS IS, Boko Haram, al Shabaab, and Al-Qaeda militants/terrorists are effectively in control. This cross-sectoral set of responses and actors will come into play after the legal and military actions can ensure sufficient access to the victims. Messaging and social media can also play a role in preventing fighters and 'wives' joining and entering the ranks.

We have discussed how the justificatory claim of "religion" in violations of women's equality needs to be thoroughly disentangled from FORB. We also have discussed the legal reasons why FORB as a human right cannot be used as grounds for violating harmful practices against women and girls, and certainly it cannot provide any justification for mass violations. However, can FORB be used as the basis for violating other less extreme rights to women's equality? For example: in relation to women's access to places of worship, ${ }^{67}$ women's roles within religious communities, or personal status codes that restrict their

64 General Comment No. 28, para. 28.

65 Joint General Recommendation/comment on harmful practices, para. 55(b).

66 Joint General Recommendation/comment on harmful practices, para. 34.

67 For examples of some recent cases, see: https://www.theguardian.com/world/2016/ apr/12/indian-temples-cannot-bar-women-rules-supreme-court; http://www.news18 .com/news/india/haji-ali-dargah-to-grant-access-to-women-trust-tells-supreme -court-1304556.html; Case of the Church of Jesus Christ of Latter-day Saints v. the United 
equality or obligatory dress codes - that is, practices that are clearly short of what might be considered to be "harmful practices"? Raday refers to these as 'lesser infringements of their human right to equality,' clearly to be distinguished from 'the most basic of their human rights' and where 'their very personhood and their capability for dissent' 68 have been taken from them.

There are certain principles that need to be recalled in addressing such dilemmas. It is vital to ensure that the right to have, be able to freely adopt and change one's religion or belief, and express or manifest that religion or belief according to one's (possibly evolving and changing) understanding should be 'guaranteed and protected in law and in practice for both men and women, on the same terms and without discrimination. ${ }^{69}$ These freedoms should not be constrained 'by, inter alia, rules requiring permission from third parties, or by interference from fathers, husbands, brothers or others. ${ }^{70}$ The UN Human Rights Committee is adamant that Article 18 on FORB cannot be relied upon 'to justify discrimination against women.' In fact, state parties should 'provide information on the status of women as regards their freedom of thought, conscience and religion, and indicate what steps they have taken or intend to take both to eliminate and prevent infringements of these freedoms in respect of women and to protect their rights against any discrimination. ${ }^{71}$

Furthermore, many areas of discrimination involve intersectional aspects, and the UN Human Rights Committee notes that discrimination against women 'is often intertwined with discrimination on other grounds such as race, colour, language, religion, political or other opinion, national or social origin, property, birth or other status. ${ }^{72}$ Hence, state parties should be cognizant of this when seeking to understand such discrimination and taking measures to counter its effects. Regarding the intersection with minority status, for example, and in relation to Article 27, the UN Human Rights Committee reminds us that the rights minorities enjoy under Article 27 of the ICCPR 'in respect of their language, culture and religion do not authorize any State, group or person to violate the right to equal enjoyment by women of any Covenant rights, including the right to equal protection of the law. ${ }^{73}$ To the contrary, this puts a further responsibility on the state to report on any legislation or practices that

Kingdom, European Court of Human Rights, Application No. 7552/o9, Judgement of 4 March 2014.

68 Frances Raday, 'Culture, Religion, and Gender,' 1:4 International Journal of Constitutional Law (2003), p. 710.

69 General Comment 28, para. 21.

70 General Comment 28, para. 21.

71 General Comment 28, para. 21.

72 General Comment 28, para. 3 o.

73 General Comment 28, para. 32 . 
such membership may give rise to in relation to infringements on the equal rights of women and their enjoyment of ICCPR rights.

In relation to the regulation of women's clothing, for example, the UN Human Rights Committee has asked state parties to 'provide information on any specific regulation of clothing to be worn by women in public,' as such regulations

may involve a violation of a number of rights guaranteed by the Covenant, such as: Article 26, on non-discrimination; Article 7, if corporal punishment is imposed in order to enforce such a regulation; Article 9, when failure to comply with the regulation is punished by arrest; Article 12, if liberty of movement is subject to such a constraint; Article 17, which guarantees all persons the right to privacy without arbitrary or unlawful interference; Articles 18 and 19, when women are subjected to clothing requirements that are not in keeping with their religion or their right of self-expression; and, lastly, Article 27, when the clothing requirements conflict with the culture to which the woman can lay a claim. ${ }^{74}$

Indeed 'many women suffer from multiple or intersectional discrimination or other forms of human rights violations on the grounds of both their gender and their religion or belief, ${ }^{75}$ and polarizing questions around the human rights to FORB and women's equality can render their cases invisible.

Raday captures the balance to be struck between respecting women's autonomy and not being negligent of the role of the state in these scenarios of 'lesser infringements' as distinct from harmful practices. She argues that the authorities cannot be indifferent to the 'quality' of women's consent and that it is incumbent upon them to 'establish the conditions for genuine, free and informed consent. ${ }^{76}$ This requires the authorities to put in place 'a spectrum of measures to create an educational and economic infrastructure that will

74 General Comment No. 28, para. 13. See also Stephanie Berry, 'A "Good Faith" Interpretation of the Right to Manifest Religion? The Diverging Approaches of the European Court of Human Rights and the UN Human Rights Committee,' 35:3 Legal Studies (2016); Karima Bennoune, 'Secularism and Human Rights: A Contextual Analysis of Headscarves, Religious Expression, and Women's Equality under International Law, 45:2 Columbia Journal of Transnational Law (2006).

75 Report of the Special Rapporteur Heiner Bielefeldt on freedom of religion or belief, Addressing the Interplay of Freedom of Religion or Belief and Equality between Men and Women, A/68/29o (2013), para. 17.

$7^{6}$ Frances Raday, 'Culture, Religion, and Gender,' 1:4 International Journal of Constitutional Law (2003), p. 710. 
augment women's autonomy, indeed, that will offer women's autonomy as an alternative. 77

\section{Conclusion: Transcending the Barriers, Addressing the Divide}

This article has sought to disentangle "religion" from ғORB in terms of justificatory claims for restrictions on women's equality, and to discuss each in turn. It has noted the scale of the challenge both in terms of the perceptions of a clash and as contributing factors that lead to violations. This leaves us with the overarching objective to seek, instead, to promote synergies between women's rights to equality and FORB.

We have observed that in terms of both its legal norms and mechanisms, the UN Human Rights Committee is best placed within the UN system to address synergies concerning women, equality, and FORB. Indeed the UN Human Rights Committee has been able to address women's equality very effectively in a number of its General Comments. However, it has not yet taken the opportunity to focus attention on synergies between women's rights to equality and FORB. In doing so, the committee could benefit from the groundwork the Special Rapporteur on FORB has done in addressing this theme. ${ }^{78}$ The committee can also play a much more consistent role in encouraging state parties to consider this interrelatedness, and can bring up the interrelatedness and synergies in the constructive dialogue it holds with states and in the recommendations it makes to them.

Since CEDAW is the UN body central to tackling discrimination against women, it should be encouraged to promote synergies between women's rights to equality and FORB. Although there is no mention of FORB in the text of the CEDAW convention, the committee can suggest such synergies in its recommendations to state parties in response to the constructive dialogue it holds with them. In its joint general recommendation/comment with the CRC on harmful practices, CEDAW has started to recognize the importance of a positive role for religious authorities ${ }^{79}$ in contributing to the vertical coordination between actors at different levels (local, regional, and national) in building a civil society bulwark of prevention and protection against such harmful practices. This understanding needs to be expanded to better recognize the

\footnotetext{
$77 \quad$ Ibid.

78 Report of the Special Rapporteur Heiner Bielefeldt on freedom of religion or belief, Addressing the Interplay of Freedom of Religion or Belief and Equality between Men and Women, A/68/29o (2013).

79 Joint General Recommendation/comment on harmful practices, para. 34.
} 
role religious messaging, religious nongovernmental organizations, and FORB itself can play in countering harmful practices and in relation to mass violations against women in the context of terrorist ideologies. It needs to be better understood that becoming religiously or "FORB-literate" and aware in this struggle to promote the equality of women is not counterproductive and counterintuitive, but rather can potentially mobilize positive forces in addressing root causes of exploitation and disempowerment. This will also assist CEDAW to take on board more intersectional understandings in its recommendations to state parties as well as in assessing individual communications. A joint General Comment/recommendation by the UN Human Rights Committee and the CEDAW Committee will be able to contribute powerfully to advancing this platform, but it should be noted that to date, the UN Human Rights Committee has not issued any joint General Comments.

Much preparation is necessary before the readiness and appetite for the promotion of synergies between FORB and women's rights to equality can be realistically expected. In the UN, as discussed, the UN Special Rapporteur on FORB and the UN Human Rights Committee have most readiness. CEDAW, the CRC, and the UN Working Group on discrimination against women in law and practice are the actors that may need the most encouragement to set aside fears that any synergies between FOR B and women's rights to equality may only serve to further violate the rights of women and girls. Their constituents, too, need this encouragement, and the respective civil society communities working for women's rights and FORB need to be brought together more effectively. There must be a mobilizing role - through the hosting of fora and debates - to nurture these connections. The UN Special Rapporteur on cultural rights may serve to open up the discussion of traditional and religious values and culture in a way that can advance human rights understandings of the necessary synergies between these equalities and freedoms.

There are areas of work within the UN and the Organization for Security and Co-operation in Europe (OSCE) in relation to preventing and countering violent extremism and promoting security in human-rights-compliant ways that bring together concerns for promoting both FORB and women's equalities as conduits for security and the prevention of extremism. These have created constituents that understand the need for these synergies well. Such understandings for these synergies now need to be broadened far beyond the security concern. Synergies between FORB and women's rights to equality are coherent to the human rights project in itself, necessary to the protection of both FORB and women's equality, and provide the only way of effectively addressing intersectional concerns in the global community. 